\title{
Analysis of the fermentative profile of yeasts isolated from natural sources
}

\author{
Avaliação do perfil fermentativo de leveduras isoladas de fontes naturais \\ Evaluación del perfil fermentativo de levaduras aisladas de fuentes naturales
}

Received: 08/05/2021 | Reviewed: 08/11/2021 | Accept: 08/12/2021 | Published: 08/15/2021

\author{
Elane Galvão dos Santos \\ ORCID: https://orcid.org/0000-0003-0715-5585 \\ Universidade Estadual de Mato Grosso do Sul, Brazil \\ E-mail: elanegalvao.santos@gmail.com \\ Rebeca Fasioli Silva \\ ORCID: https://orcid.org/0000-0002-9649-0619 \\ Universidade Estadual de Mato Grosso do Sul, Brazil \\ E-mail: beca_fasioli@hotmail.com \\ Maria do Socorro Mascarenhas Santos \\ ORCID: https://orcid.org/0000-0002-5343-4502 \\ Universidade Estadual de Mato Grosso do Sul, Brazil \\ E-mail: maria_mascarenhas@outlook.com \\ Margareth Batistote \\ ORCID: https://orcid org/0000-0001-9865-2362 \\ Universidade Estadual de Mato Grosso do Sul, Brazil \\ E-mail: margarethbatistote@gmail.com
}

\begin{abstract}
The natural environment aggregates an immense amount of microorganisms, some unknown and others still unexplored and that may have the potential for the production of compounds. Thus, this study aims to evaluate the fermentative profile of isolates from natural sources under different growing conditions. For this purpose, the plating performing on a $2 \%$ YPD solid medium incubating in an oven at $30{ }^{\circ} \mathrm{C}$. The isolated colonies use for the carbon source assimilation test, which carried out through cell growth. Carrying out in test tubes containing the YP fermentative added with carbon sources (glucose, lactose, sucrose, fructose, mannose, maltose, starch) with a concentration of $17{ }^{\circ} \mathrm{Brix}$, at $\mathrm{pH} 4$ and 6 , incubated at 28 and $35{ }^{\circ} \mathrm{C}$ and at different times of cultivation, aliquots removed for analysis. For the control, the yeast Catanduva-1 was used. The isolates grew in the range of $\mathrm{pH} 4 \mathrm{and} \mathrm{pH}$ 6 at $28{ }^{\circ} \mathrm{C}$ and isolate A4 showed greater growth at a temperature of $35^{\circ} \mathrm{C}$. Isolates A4, A5, and A6 used most sugars except for lactose. Isolate A2 assimilated glucose and fructose and A6 showed a fermentation profile similar to standard yeast.
\end{abstract}

Keywords: Prospecting; Saccharomyces cerevisiae; Biocatalysis; Fermentation.

\section{Resumo}

O meio ambiente natural agrega uma imensa quantidade de microrganismos, alguns desconhecidos e outros ainda pouco explorados e que podem apresentar potencial para produção de compostos. Assim, este estudo visa avaliar o perfil fermentativo de isolados de fontes naturais em diferentes condições de cultivo. Para tanto foi realizado um plaqueamento em meio sólido YPD $2 \%$ incubadas em estufa a $30{ }^{\circ} \mathrm{C}$. As colônias isoladas foram utilizadas para $\mathrm{o}$ teste de assimilação de fontes de carbono que foi feito através do crescimento celular e foi realizado em tubos de ensaio contendo o fermentativo YP acrescido das fontes de carbono (glicose, lactose, sacarose, frutose, manose, maltose, amido) com concentração de $17^{\circ}$ Brix, em pH 4 e 6 incubados em 28 e $35^{\circ} \mathrm{C}$ e em diferentes tempos de cultivo alíquotas foram retiradas para as análises. Para o controle foi utilizada a levedura Catanduva-1. Os isolados cresceram na faixa de $\mathrm{pH} 4$ e pH 6 a $28{ }^{\circ} \mathrm{C}$ e o isolado A4 mostrou maior crescimento na temperatura de $35{ }^{\circ} \mathrm{C}$. Os isolados A4, A5, e A6 utilizaram à maioria dos açúcares exceto para a lactose. O isolado A2 assimilou glicose e frutose e o A6 mostrou um perfil fermentativo semelhante a levedura padrão.

Palavras-chave: Prospecção; Saccharomyces cerevisiae; Biocatalise; Fermentação.

\section{Resumen}

El medio natural agrega una inmensa cantidad de microorganismos, algunos desconocidos y otros aún inexplorados y que pueden tener potencial para la producción de compuestos. Así, este estudio tiene como objetivo evaluar el perfil fermentativo de aislados de fuentes naturales en diferentes condiciones de cultivo. Para este propósito, se realizó la siembra en placa en un medio sólido de YPD al $2 \%$ incubado en un horno a $30{ }^{\circ} \mathrm{C}$. Las colonias aisladas se utilizaron para la prueba de asimilación de la fuente de carbono, que se realizó mediante crecimiento celular y se realizó en probetas que contenían el fermentativo YP agregado con fuentes de carbono (glucosa, lactosa, sacarosa, fructosa, manosa, maltosa, almidón) con a una concentración de $17^{\circ} \mathrm{Brix}$, a pH 4 y 6 , incubados a 28 y $35^{\circ} \mathrm{C}$ y en diferentes 
momentos de cultivo, se retiraron alícuotas para su análisis. Para el control se utilizó la levadura Catanduva-1. Los aislamientos crecieron en el rango de $\mathrm{pH} 4$ y pH 6 a $28{ }^{\circ} \mathrm{C}$ y el aislado A4 mostró mayor crecimiento a una temperatura de $35^{\circ} \mathrm{C}$. Los aislamientos A4, A5 y A6 utilizaron la mayoría de los azúcares excepto la lactosa. La glucosa y fructosa asimiladas del aislamiento A2 y el A6 mostraron un perfil de fermentación similar al de la levadura estándar.

Palabras clave: Prospección; Saccharomyces cerevisiae; Biocatálisis; Fermentación.

\section{Introduction}

In Brazil, biofuel production relies on advanced technology aimed at first-generation production. Such advances range from the improvement of raw material production techniques with the development of more productive varieties that contain higher sucrose concentrations to the selection of fermenting microorganisms, yeasts (Amorim \& Lopes, 2013). In this country, the production of ethanol follows good growth prospects, since it has a prominent role recognized as the second-largest producer of this biofuel, having as principle the use of direct fermentation substrates that are metabolized by Saccharomyces cerevisiae yeasts (Ferreira Junior et al., 2012; Brow et al., 2013).

These microorganisms are chosen according to their ability to adapt and respond to the peculiarities existing in the fermentation vats. This choice is based on the need to improve the conversion process, since yeast strains tolerant to industrial conditions are needed and wild yeasts stand out, thus guaranteeing a fermentation process with good productivity (Amorim et al., 2010; Fiedurek et al., 2011; Zhang et al. 2019). These strains must also have as attributes the tolerance to inhibitory compounds, ferment at low pH, at mild temperatures and have high cell viability (Amorim \& Lopes, 2013).

The ethanol production process is a hostile environment that needs monitoring, especially in relation to the control and adjustment of technical operational parameters, as in this environment are the yeasts that will conduct the sucrose biocatalysis process and any disturbance that may occur can influence the loss of cell viability resulting in ethanol production losses. In the fermentation process, selected yeasts that have a high tolerance to industrial stress factors are used (Moreira et al., 2015). Thus, yeasts are required with the capacity to adapt to stress factors and which stand out from contamination, also having a high viability rate (Da Silva Santos et al., 2018).

It is clear that the conditions of the environment, whether natural or in the industrial process, such as fermentation vats, are able to determine the characteristics of the microorganisms that are present there, so if exposed to a variation in temperature, osmotic pressure and $\mathrm{pH}$, the same microorganism may show differences in its metabolism, demonstrating its ability to adapt to different conditions and ecosystems (Della-Bianca et al., 2013), for yeasts this ability is an important characteristic.

According to Dionisi et al. (2012), the natural environment constitutes a reserve that aggregates a huge amount of microorganisms, some unknown and many are still little explored, but which can have great potential. Especially given the existing genetic diversity and ability to adapt and evolution can produce numerous compounds of biotechnological interest. The search for new yeast isolates from natural environments can contribute to the understanding of the numerous and complex cellular mechanisms; present in Saccharomyces cerevisiae.

Aiming at the understanding of metabolism, biochemistry and genetics to use them in different processes and areas of knowledge as scientific, industrial and biotechnological applications. The search for new yeast strains can also provide a better production of products obtained from fermentation such as ethanol, and can also ensure and increase the list of selected and customized strains, having as a premise the efficient production of metabolites.

In this context, the selection of new yeast strains that have potential resistance to disturbances in the ethanol production process, is a strategy to ensure the competitiveness of the fermentation process as well as productivity efficiency (Batistote \& Santos, 2020). Thus, this study aims to evaluate the fermentation profile of isolates from natural sources under different growing conditions. 


\section{Methodology}

\subsection{Sample collection and study site}

Microorganism samples were collected from different natural environments, placed in plastic bags at $\left(-4{ }^{\circ} \mathrm{C}\right)$ and transported to the Biotechnology, Biochemistry and Biotransformation laboratory of the Centro de Estudos em Recursos Naturais - CERNA, at the Universidade Estadual de Mato Grosso do Sul - UEMS.

\subsection{Yeast isolation}

The samples were homogenized in saline solution $(0.85 \%)$, then serial dilutions of the $10^{-1}, 10^{-2}$ and $10^{-3}$ were performed and $100 \mu \mathrm{L}$ of the dilutions were spread in Petri dishes containing the solid medium YPD (yeast extract $\left(10 \mathrm{~g} \mathrm{~L}^{-1}\right)$, peptone $\left(20 \mathrm{~g} \mathrm{~L}^{-1}\right)$, dextrose $\left(20 \mathrm{~g} \mathrm{~L}^{-1}\right)$, and Agar $\left(20 \mathrm{~g} \mathrm{~L}^{-1}\right)$, with the addition of the antibiotic Chloramphenicol $\left(2 \% \mathrm{v} \mathrm{v}^{-1}\right)$, spread with the aid of a Drigalski loop and incubated at $30^{\circ} \mathrm{C}$ for 72 hours.

\subsection{Assimilation of carbon sources}

YP medium (yeast extract $\left(10 \mathrm{~g} \mathrm{~L}^{-1}\right)$, peptone $\left(20 \mathrm{~g} \mathrm{~L}^{-1}\right)$; supplementing with different carbon sources (glucose, maltose, mannose, sucrose, fructose, lactose, starch). At one final concentration of total soluble solids of $17{ }^{\circ} \mathrm{Brix}, 20 \mathrm{~mL}$ adding in a test tube, and then sterilized in an autoclave at $120{ }^{\circ} \mathrm{C}$ for 20 minutes. With the aid of a platinum loop, a colony of the isolates, previously grown, was diluted in saline solution $(0.85 \%)$ and $100 \mu \mathrm{L}$ was inoculated in tubes that remained incubated in an oven for 24 hours at a temperature of $30^{\circ} \mathrm{C}$. The assimilation of carbon sources was analyzed using a portable refractometer with a scale of $0-32{ }^{\circ} \mathrm{Brix}$. The Catnaduva- 1 strain, a reference in ethanol production was used as a comparison standard.

\subsection{Pre-inoculum}

For the pre-inoculum, $2 \%$ YPD medium was used, added to a test tube and $20 \mathrm{~mL}$ and sterilized at $120{ }^{\circ} \mathrm{C}$ for 20 minutes. A colony of the isolates was diluted in saline solution $(0.85 \%)$ and $100 \mu \mathrm{L}$ was added to the medium, which was incubated at $30^{\circ} \mathrm{C}$ for 12 hours. After this period, the cells were centrifuged and washed 3 consecutive times in saline solution $(0.85 \%)$ and the biomass obtained was used in the fermentation experiments.

\subsection{Temperature and $\mathrm{pH}$ evaluation}

In the evaluation of the action of temperature and $\mathrm{pH}$ on the growth of the yeast isolates, $20 \mathrm{~mL}$ of YPD liquid medium was used in a total soluble solids concentration of $17^{\circ}$ Brix, placed in test tubes with $\mathrm{pH}$ adjustment in the range of 4.0 and 6.0 using hydrochloric acid $\left(1 \mathrm{~mol} \mathrm{~L}^{-1}\right)$ and measured with a digital $\mathrm{pH}$ meter. The tubes with the culture medium sterilized at $120{ }^{\circ} \mathrm{C}$ for 20 minutes. The biomass obtained in the pre-inoculum added to test tubes that remained incubated at temperatures of 28 and $35{ }^{\circ} \mathrm{C}$. At times (3, 6, 9 and 12 hours), aliquots were removed for cell growth analysis by spectrophotometer at $570 \mathrm{~nm}$.

\subsection{Data analysis}

Data were analyzed using Excel software with the result for the consumption of carbon sources presented as a percentage and the others as mean and standard deviation. 


\section{Results and Discussion}

\subsection{Assimilation of carbon sources}

In evaluating the assimilation of different carbon sources of yeast isolates obtained from natural sources, the isolates will assimilate the evaluated carbon sources, demonstrating higher consumption of sucrose, glucose and fructose. Isolate A3 only assimilating sucrose, glucose and fructose sources. Isolates A4, A5, and A6 showed assimilation of most sugars except for lactose. Sample A6 showed some similarity with the standard Cat-1, as it assimilated the carbon source glucose and fructose. However, the assimilation of sucrose presented by this sample (A6) was low compared to Cat-1, A4 and A5, possibly this fact may be related to the production of the enzyme invertase, as the yeast Cat-1 has a high capacity to produce this enzyme in an amount that enables the efficient breaking down of sucrose. The data suggest that the sample (A6), although it is capable of assimilating free glucose and fructose, does not have an efficient production of an enzyme that performs the biocatalysis of sucrose into glucose and fructose. Lactose was not assimilated by most of the isolates, except for sample A2 (Table 1). It was observed that yeasts isolated from natural environments or different habitats, showed versatile growth and metabolism in relation to the consumption of carbon sources. Perhaps because they present such attributes, they can be used in several biotechnological processes.

Table 1. Assimilation of carbon sources by yeast isolates obtained from natural sources and cultivated in the substrate with a total soluble solids concentration of $17^{\circ}$ Brix.

\begin{tabular}{ccccccc}
\hline & \multicolumn{7}{c}{ Total Soluble Solids Consumption (\%) } \\
\cline { 2 - 7 } Carbon sources & Cat-1 & A2 & A3 & A4 & A5 & A6 \\
\hline Sucrose & 41,2 & 11,8 & 5,9 & 17,6 & 17,6 & 11,8 \\
Glucose & 41,2 & 17,6 & 5,9 & 23,5 & 17,6 & 41,4 \\
Fructose & 35,3 & 17,6 & 11,8 & 23,5 & 23,5 & 30,2 \\
Lactose & $\mathrm{nc}$ & 11,8 & $\mathrm{nc}$ & $\mathrm{nc}$ & $\mathrm{nc}$ & $\mathrm{nc}$ \\
Mannose & 11,8 & $\mathrm{nc}$ & $\mathrm{nc}$ & 17,6 & 11,8 & 11,8 \\
Maltose & 17,6 & 11,8 & $\mathrm{nc}$ & 11,8 & 11,8 & 11,8 \\
Starch & $\mathrm{nc}$ & 11,8 & $\mathrm{nc}$ & 11,8 & 11,8 & 11,8 \\
\hline
\end{tabular}

Did not consume (nc). Source: Authors.

S. cerevisiae yeasts are microorganisms that have a high capacity to produce enzymes, especially invertase, which catalyzes sucrose, a sugar composed of glucose and fructose. The sucrose catalysis leaves free glucose and fructose in the medium, thus being easily assimilated by yeasts (Bhalla et al., 2017). This process of breaking down sucrose provides the yeast with a rich source of nutrients for its metabolism.

Saccharomyces cerevisiae has a versatile metabolism, as it survives in a wide range of environments, such as fruits, peels, soil, hostile environment, with different nutrient availability, containing low and high concentrations of carbon and nitrogen sources (Wenger et al., 2011). Yeasts used in fermentation processes for the production of ethanol must have the capacity to metabolize sucrose, glucose and fructose, such carbon sources mainly sucrose is the major sugar present in sugarcane. (Basso et al., 2011; Mattanovich et al., 2014).

The assimilation of carbon sources can indicate the type of substrate in which the yeasts were found and from this finding correlate to their reflecting specificities and nutritional requirements. However, yeasts can be chemo-organotrophic and have the ability to use different sugars for their metabolism (Compagno et al., 2014). 


\subsection{The effect of temperature and $\mathrm{pH}$ on cell growth of yeast isolates}

In evaluating the cell growth of yeast isolates from natural environments, concerning temperature and $\mathrm{pH}$, it was observed that the isolates showed better growth at the temperature of $28{ }^{\circ} \mathrm{C}$, in the range of $\mathrm{pH} 4$ and 6 in 12 hours. However, sample A2 only grew at $\mathrm{pH} 6$ (Figure 1). Changes in temperature and $\mathrm{pH}$ are some of the factors that affect the physiological mechanisms of yeasts, directly interfering with their survival, resulting in reduced viability, loss of metabolites, and chan ges in cell growth.

One of the success factors for industrial fermentation processes is the constant monitoring of $\mathrm{pH}$ to control contamination. The development of yeasts in the fermentation rate and the formation of by-products depends on factors, in addition, industrial must usually have a pH between 4.5 to 5.5, being the ideal range for industrial yeasts (Moreira et al., 2015). Yeasts of the genus Saccharomyces cerevisiae have an ideal $\mathrm{pH}$ range for their growth, 4.5. However, sugarcane juice usually has a $\mathrm{pH}$ of around 5.5, the juice is acidified before the addition of yeasts to promote alcoholic fermentation and also to prevent the growth of contaminating bacteria that can harm the yield of the process (Ribeiro, 2010).

Figure 1. Analysis of cell growth of yeast isolates obtained from natural environments and the standard Catanduva-1, grown in $2 \%$ YPD medium at $17^{\circ} \mathrm{Brix}$ at $\mathrm{pH} 4$ and 6 at $28^{\circ} \mathrm{C}$.
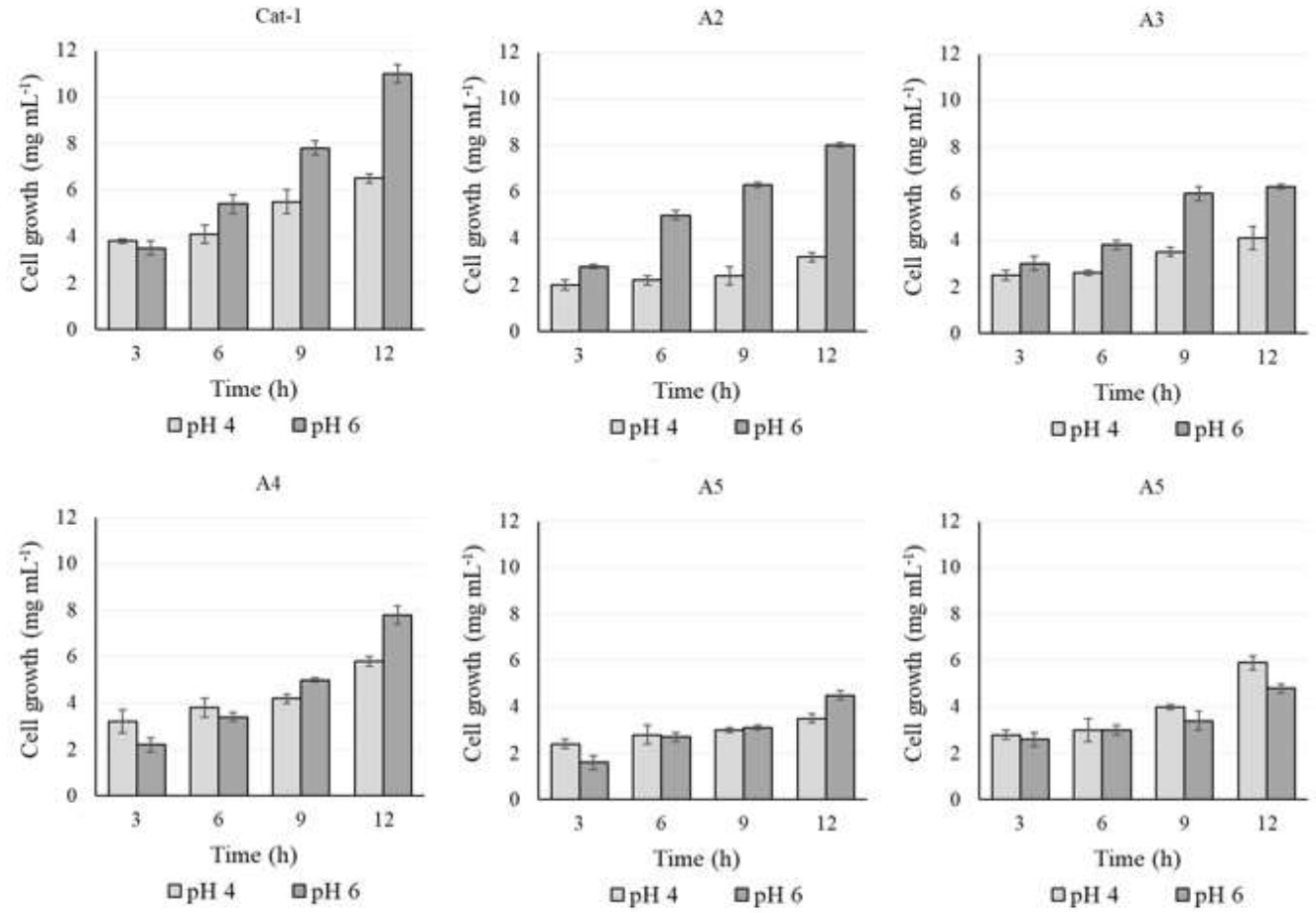

Source: Research data.

At a temperature of $35^{\circ} \mathrm{C}$, the isolates analyzed showed growth at the respective $\mathrm{pH} 4$ and 6 but were more sensitive to the action of temperature. However, isolate A4 showed the highest growth at both pHs in 12 hours of growth, a profile similar to yeast Catanduva-1, suggesting that the isolate has characteristics of tolerance to higher temperatures (Figure 2). In the industrial process for ethanol production, it is more interesting that yeasts are more resistant to high temperatures, so the search for new isolates that present this characteristic of thermotolerant can represent a differential for the process and result in economic and environmental gains.

Yeasts can adapt to environments and temperature variations. In the natural environment, these microorganisms are in constant contact with different temperatures due to climatic conditions, in this context the environment provides the existence 
of thermotolerant yeasts (Tofighi et al., 2014). For the industrial ethanol fermentation process, the use of thermotolerant yeasts can represent an economic gain, since the costs of cooling the juice can be minimized (Abdel-Banat et al., 2010). Environmental, since the cooling of the juice, is performed employing heat exchangers that use water in constant circulation, thus representing a decrease in the use of this natural resource (Tofighi et al., 2014). These authors emphasize that the thermotolerant capacity of yeasts has been attracting attention with a view to the possibilities of their use in different bioprocesses.

According to Ribeiro (2010), the $\mathrm{pH}$ can vary for several reasons during the fermentation process, such variations can be related to factors such as the availability of nitrogen sources and the formation of acids, and must be monitored periodically. For Cruz et al. (2015), different temperatures distinctly affect the metabolic activity and growth of yeast, thus constituting one of the factors that can interfere in the fermentation process, as they present their metabolic efficiency between $25{ }^{\circ} \mathrm{C}$ and $30{ }^{\circ} \mathrm{C}$ (Sousa \& Monteiro, 2012).

Figure 2. Analysis of cell growth of yeast isolates obtained from natural environments and the standard Catanduva-1, cultivated in YPD $2 \%$ medium at $17^{\circ}$ Brix at $\mathrm{pH} 4$ and 6 at a temperature of $35^{\circ} \mathrm{C}$.
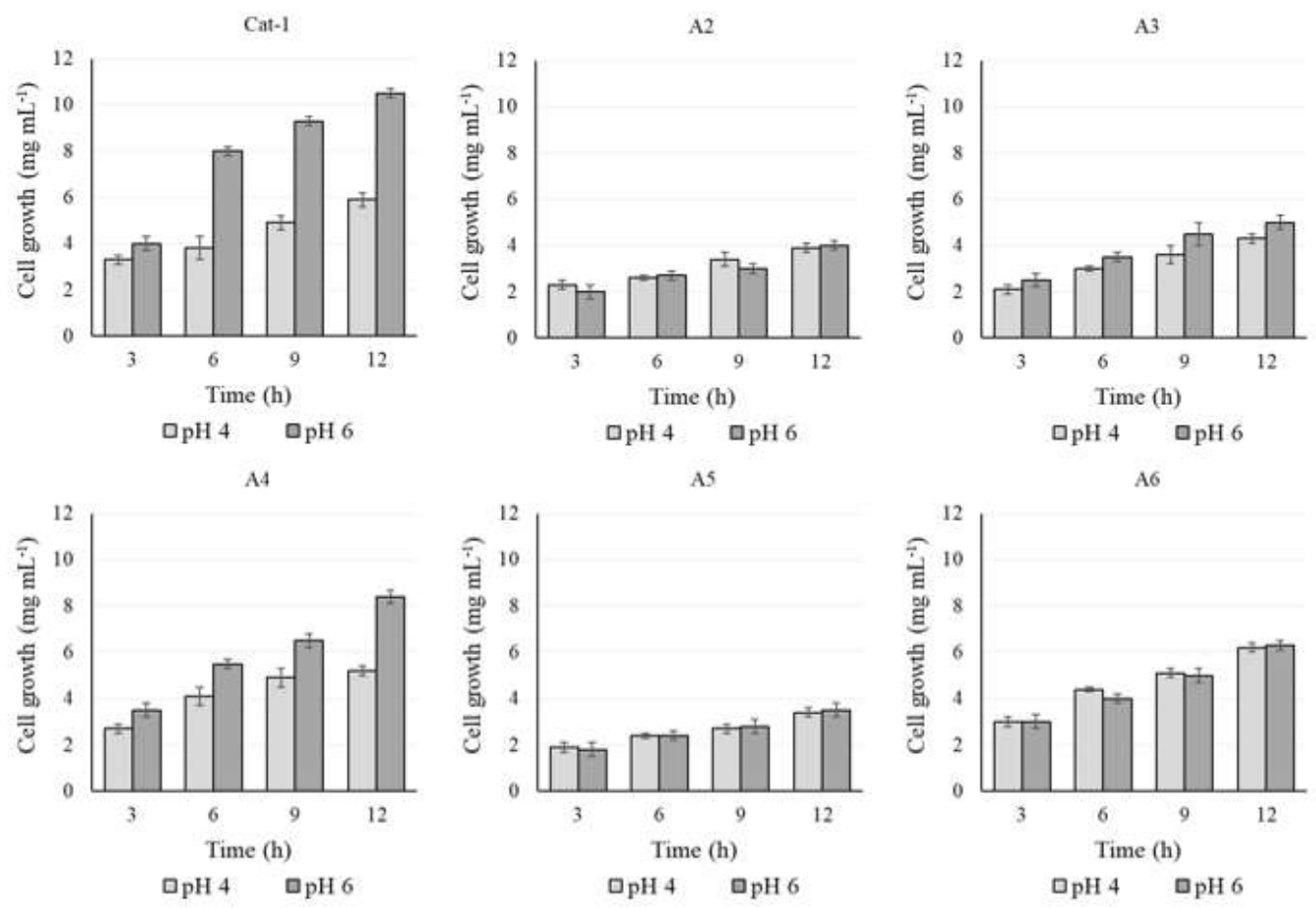

Source: Research data.

Studies developed by Mueller et al. (2020) comparing the physiological response of Fleischmann®, Pedra-2 and FT858 yeasts in fermentation medium containing different concentrations of ethanol $(5,10$ and $15 \%)$ and at temperatures of 30 ${ }^{\circ} \mathrm{C}$ and $40{ }^{\circ} \mathrm{C}$. They observed that the higher temperature interfered with the growth of yeast colonies and that, when associated with a higher concentration of ethanol, this inhibition was more effective and that the synergism of stress factors can lead to cell death.

The yeasts used in the fermentation process are strains isolated from the fermentation process itself and were named after the plants where they were identified (Amorim \& Lopes, 2013). Some yeast strains can assimilate different carbon sources and from their metabolic routes produce several other compounds in addition to ethanol and glycerol (Jullesson et al., 2015; Tortora et al., 2012). These microorganisms are considered to be excellent producers of compounds of natural origin that 
are required for their high degree of purity. Such products are formed through the activation of certain metabolic pathways, in which essential nutrients for the maintenance of cells and their physiological functions are shared.

\section{Conclusion}

Isolates A2, A4 and A6 assimilated glucose and fructose. Isolate A6 showed a fermentation profile similar to that of standard yeast. Isolates A4, A5, and A6 used most sugars except lactose. Yeasts isolated from natural sources showed cell growth in the range of $\mathrm{pH} 4$ and 6 at $28{ }^{\circ} \mathrm{C}$ for 12 hours. For a temperature of $35^{\circ} \mathrm{C}$, isolate A4 showed better growth when compared to the others.

Studies aimed at finding new yeasts with an ideal profile for fermentation are important since yeast has a fermentative efficiency and high capacity to stand out from stress factors. Especially those that support higher temperature, may make technological development of the more profitable ethanol production process, directly contributing to better production of this important biotechnological product.

The results are promising and from them other analyzes can be performed, mainly in relation to tolerance to different concentrations of ethanol and osmotic pressure

\section{Acknowledgments}

This study was financed in part by the Coordenação de Aperfeiçoamento de Pessoal de Nível Superior - Brasil (CAPES) - Finance Code 001 for MSMS.

\section{References}

Abdel-Banat, B. M., Hoshida, H., Ano, A., Nonklang, S., \& Akada, R. (2010). High-temperature fermentation: how can processes for ethanol production at high temperatures become superior to the traditional process using mesophilic yeast? Applied microbiology and biotechnology, 85(4), 861-867.

Amorim, H. V., Gryschek, M., \& Lopes, M. L. (2010). The success and sustainability of the Brazilian sugarcane- fuel ethanol industry. In Sustainability of the Sugar and Sugar- Ethanol Industries (pp. 73-82). American Chemical Society.

Amorim, H. V., \& Lopes, M. L. (2013). Ciência e tecnologia na seleção de leveduras para produção de etanol. Microrganismos em Agroenergia: da Prospecção aos Bioprocessos. Brasília: Embrapa Agroenergia, 42-59.

Basso, T. O., de Kok, S., Dario, M., do Espirito-Santo, J. C. A., Müller, G., Schlölg, P. S., Silva C. P., Tonso, A., Daran, J. M., Gombert, A. K., van Maris, A. J. A., Pronk, J. T., \& Stambuk, B. U. (2011). Engineering topology and kinetics of sucrose metabolism in Saccharomyces cerevisiae for improved ethanol yield. Metabolic engineering, 13(6), 694-703.

Batistote, M., \& Santos, M. D. S. M. (2020). Analysis of fermentative parameters and the importance of Saccharomyces cerevisiae in the development of goods and services. Research, Society and Development, 9(11), e93691110586-e93691110586.

Bhalla, T. C., Thakur, N., \& Thakur, N. (2017). Invertase of Saccharomyces cerevisiae SAA-612: Production, characterization and application in synthesis of fructo-oligosaccharides. $L W T, 77,178-185$.

Brown, N. A., de Castro, P. A., de Castro Pimentel Figueiredo, B., Savoldi, M., Buckeridge, M. S., Lopes, M. L., \& Goldman, G. H. (2013). Transcriptional profiling of Brazilian Saccharomyces cerevisiae strains selected for semi-continuous fermentation of sugarcane must. FEMS Yeast Research, 13(3), 277-290.

Compagno, C., Dashko, S., \& Piškur, J. (2014). Introduction to carbon metabolism in yeast. In Molecular mechanisms in yeast carbon metabolism (pp. 1-19). Springer, Berlin, Heidelberg.

Cruz, M., Raminho, M., Castro, A., Guidini, C., Resende, M. D., \& Ribeiro, E. (2014). Estudo da influência da Temperatura na Resistência ao Etanol da Levedura Saccharomyces cerevisiae Y904. In XX Congresso Brasileiro de Engenharia Química.

Da Silva Santos, A. F., Santos, M. D. S. M., Maia, F. S., Cardoso, C. A. L., \& Batistote, M. (2018). Perfil de produção de etanol e trealose em Saccharomyces cerevisiae cultivadas em mosto a base de caldo de cana. Scientia Plena, 14(7).

Della-Bianca, B. E., Basso, T. O., Stambuk, B. U., Basso, L. C., \& Gombert, A. K. (2013). What do we know about the yeast strains from the Brazilian fuel ethanol industry? Applied microbiology and biotechnology, 97(3), 979-991.

Dionisi, H. M., Lozada, M., \& Olivera, N. L. (2012). Bioprospection of marine microorganisms: biotechnological applications and methods. Revista Argentina de Microbiología, 44(1), 49-60. 
Research, Society and Development, v. 10, n. 10, e445101019127, 2021

(CC BY 4.0) | ISSN 2525-3409 | DOI: http://dx.doi.org/10.33448/rsd-v10i10.19127

Ferreira Junior, R. A., Souza, J. L. D., Lyra, G. B., Teodoro, I., Santos, M. A. D., \& Porfirio, A. (2012). Crescimento e fotossíntese de cana-de-açúcar em função de variáveis biométricas e meteorológicas. Revista Brasileira de Engenharia Agrícola e Ambiental, 16(11), $1229-1236$.

Fiedurek, J., Skowronek, M., \& Gromada, A. (2011). Selection and adaptation of Saccharomyces cerevisae to increased ethanol tolerance and production. Pol J Microbiol, 60(1), 51-58.

Hahn-Hägerdal, B., Karhumaa, K., Fonseca, C., Spencer-Martins, I., \& Gorwa-Grauslund, M. F. (2007). Towards industrial pentose-fermenting yeast strains. Applied microbiology and biotechnology, 74(5), 937-953.

Jullesson, D., David, F., Pfleger, B., \& Nielsen, J. (2015). Impact of synthetic biology and metabolic engineering on industrial production of fine chemicals. Biotechnology advances, 33(7), 1395-1402.

Mattanovich, D., Sauer, M., \& Gasser, B. (2014). Yeast biotechnology: teaching the old dog new tricks. Microbial cell factories, 13(1), 1-5.

Moreira, C. S., Santos, M. D. S. M., Barro, N. S., Cardoso, C. A. L., \& Batistote, M. (2015). Análise dos parâmetros morfofisiológicos de linhagens de leveduras industriais com potencial biotecnológico para a produção de etanol. Ciência e Natura, 37(3), 55-63.

Mueller, L. P., Santos, M. D. S. M., Cardoso, C. A. L., \& Batistote, M. (2020). The effects of thermal and ethanolic stress in industrial strains of Saccharomyces cerevisiae. Research, Society and Development, 9(10), e6819109091-e6819109091.

Ribeiro, F. A. M. (2010). Fermentação Alcoólica -Apostila do ModuloII-Processamento na indústria sucroalcooleiro, FAZU em Revista.

Sousa, J. D., \& Monteiro, R. A. B. (2012). Fatores interferentes na fermentação alcoólica para a produção de etanol. FAZU em Revista, (08).

Tofighi, A., Assadi, M. M., Asadirad, M. H. A., \& Karizi, S. Z. (2014). Bio-ethanol production by a novel autochthonous thermo-tolerant yeast isolated from wastewater. Journal of Environmental Health Science and Engineering, 12(1), 1-6.

Tortora, G. J., Funke, B. R., \& Case, C. L. (2012). Microbiologia 10a Edição.

Vasconcelos, J. N. Ethanol Fermentation In Santos, F., Borém, A., \& Caldas, C. (Eds.). (2015). Sugarcane: Agricultural production, bioenergy and ethanol. Academic Press.

Wenger, J. W., Piotrowski, J., Nagarajan, S., Chiotti, K., Sherlock, G., \& Rosenzweig, F. (2011). Hunger artists: yeast adapted to carbon limitation show tradeoffs under carbon sufficiency. PLoS genetics, 7(8), e1002202.

Zhang, Q., Jin, Y. L., Fang, Y., \& Zhao, H. (2019). Adaptive evolution and selection of stress-resistant Saccharomyces cerevisiae for very high-gravity bioethanol fermentation. Electronic Journal of Biotechnology, 41, 88-94. 